\title{
Chapter 1 \\ The Social Determinants of Health and Trends Concerning Health Disparity
}

\author{
Katsunori Kondo
}

\section{Introduction}

A society's health is determined not only by genes and lifestyle but also by social factors such as individuals' socioeconomic position and social relationships. A large number of social epidemiology studies have revealed a branch of epidemiology concerned with the way that social structures, institutions, and relationships influence health [1]. This was followed by policy responses and practical efforts, such as the recommendations in the final report of the Commission on Social Determinants of Health (WHO) [2] and similar responses from the European Union (EU) [3]. The WHO adopted resolution 62.14_-"Reducing health inequities through action on the social determinants of health" - in the World Health Assembly.

The Japanese Ministry of Health, Labour, and Welfare (MHLW) have also indicated one of the basic goals of Health Japan 21 (second term: 2013-2023, see appendices of this book) to be "the reduction of health disparities" along with "the extension of a healthy life expectancy," as shown in Fig. 1.1. By definition, health disparities refer to a gap in health status between groups created by a difference in community or socioeconomic status [1]. Health Japan 21 (first term: 2000-2010) was a 10-year plan that addressed the "comprehensive implementation of national health promotion" and was created with a focus on the lifestyles of individuals. However, this focus took away from other aspects such as its perspective on the social environment. The experience of the first term proved that individual health and improvement of an individual's social environment are inextricably linked and

\footnotetext{
K. Kondo $(\bowtie)$

Professor of Social Epidemiology and Health Policy, Department of Social Preventive Medical Sciences, Center for Preventive Medical Sciences, Chiba University, Chiba, Japan

Head of Department of Gerontological Evaluation, Center for Gerontology and Social Science, National Center for Geriatrics and Gerontology, Obu City, Aichi, Japan e-mail: kkondo@chiba-u.jp
} 


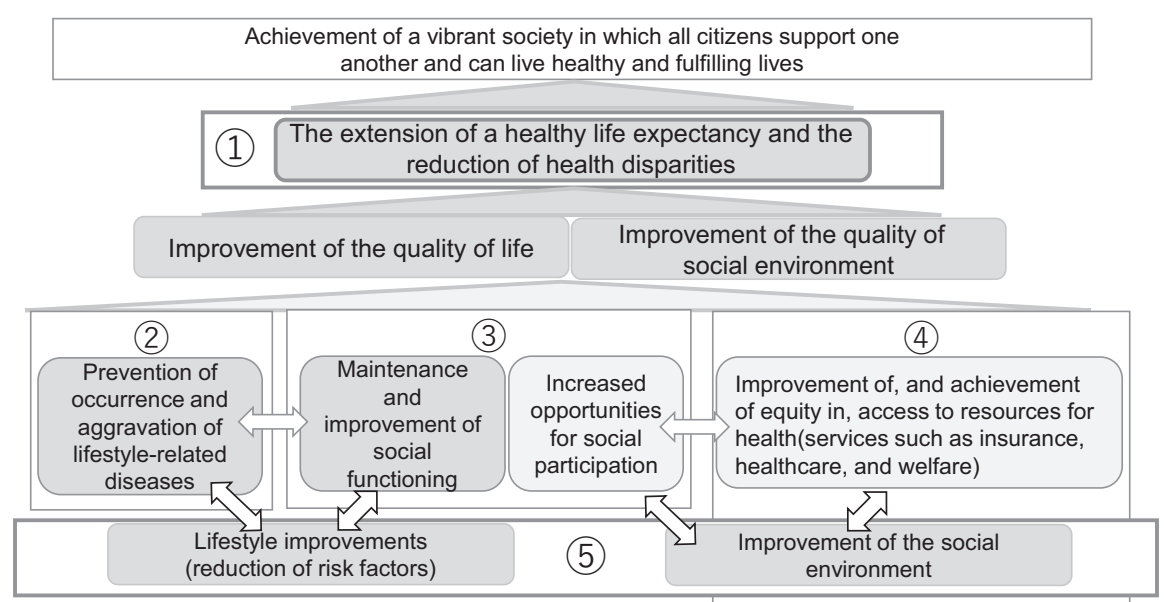

Specific initiatives in the next phase of the National Health Promotion Movement

Fig. 1.1 Conceptual diagram of Health Japan 21 (the second term) [1]

both are necessary. Therefore, the improvement of social environments should be given priority [4]. In the second term, the importance of the improvement of social environment quality was stressed. Factors that determine the quality of a social environment are indeed the social determinants of health.

This book reviews studies on social determinants of health (SDH) in noncommunicable diseases (NCDs) and healthy aging. The issues of NCDs and healthy aging are becoming global public health challenges, particularly in developing countries. Chapter 1 describes the background and objectives of this book as well as the importance of the social determinants of NCDs and healthy aging. It also provides an overview of policy responses, including that of the WHO and Health Japan 21.

\section{Policy Responses to SDH from the WHO and Europe}

Since the 1980 release of the Black Report in the United Kingdom, SDH and the problems concerning health disparities to which they give rise have piqued the interest of researchers in developed countries, particularly in Europe. Since the truth has come to light, society's interest in this issue has been growing and the policy response has begun $[3,5,6]$.

In 1991, the WHO Regional Committee for Europe had already set a goal of a $25 \%$ reduction in health disparities. The committee stated that it was the duty of governments to mobilize resources-taxation, pensions, employment, education, and state finances - and to eliminate poverty and inequality. In 1998, the United Kingdom's Acheson Inquiry reported that health inequalities had in fact grown, rather than diminished [5]. The inquiry's report argued that social environmental 
Table 1.1 Policy areas that affect health

\begin{tabular}{l}
\hline Democratic policies \\
\hline Human rights \\
\hline Media policies \\
\hline Employment policies \\
\hline Gender equality policies \\
\hline Child and youth policies \\
\hline Policies concerning the elderly \\
\hline Urban development policy \\
\hline Guarantees of income for the elderly \\
\hline The sick and the disabled \\
\hline Housing policies \\
\hline Labor market policies \\
\hline Insurance and healthcare policies \\
\hline Environmental policies \\
\hline Transportation and transportation \\
safety policies \\
\hline Accident prevention and emergency \\
healthcare policies \\
\hline Infectious disease control policies \\
\hline Education policies \\
\hline Crime prevention policies \\
\hline Sports policies \\
\hline Food and nutrition policies \\
\hline Taxation \\
\hline The judicial system \\
\hline
\end{tabular}

factors, such as poverty, food environment, and employment, had affected individuals' health. The government took responsibility for these findings and announced an action plan in the same year in which the report was published [6]. Five years later, in 2003, the government again released a plan of action to deal with the problem [7]. This program announced measures that included the participation of the Prime Minister's Office, the Cabinet Office, the Treasury, and the Department of Trade and Industry-in addition to that of the Department of Health-as well as numerical targets to be reached by 2010 .

In Sweden, numerous policy responses, such as those shown in Table 1.1, were discussed. Furthermore, the 2003 revision to the law on Public Health Objectives explicitly stated the importance of "economic and social security." [8]

In 2005, the WHO implemented the Commission on Social Determinants of Health, and in October of the same year, the United Kingdom, who held the EU presidency at the time, organized an EU summit with the theme of overcoming health inequalities. Ministers, politicians, and senior government officials from 36 countries and numbering $\mathbf{5 7 0}$ officials attended the summit and agreed to redouble their efforts to reduce health inequality and its related problems. Numerical targets for eliminating health inequalities were established in several countries, including 
the Netherlands, Finland, the United Kingdom, and Ireland, and these countries started implementing their respective policy responses.

In 2008, the WHO Commission on Social Determinants of Health released its final report. This document presented three recommendations: first, it recommended improving the daily living conditions of all people, from childhood throughout their entire lives. The background of this recommendation was the accumulation of research into life course epidemiology (see Chap. 15), which demonstrates a clear link between factors in the childhood environment-including birth weight and preschool education - and health conditions in later life. Second, the report recommended that inequitable distributions of power, money, and resources need to be addressed. One factor giving rise to health inequalities is differences in lifestyle. However, this factor alone can only explain approximately $20-30 \%$ of the gap. In other words, it has become clear that it is important to correct or lessen inequalities in themselves. The third recommendation stated that it is crucial to measure health inequalities, to have a more in-depth understanding of them, and to evaluate (estimate) the impact of policies when designing measures such as those suggested by the WHO report. In summary, the report suggested the following steps: recognition that health inequalities are a problem and the measurement of these inequalities is a priority; creation of surveillance systems to monitor health inequalities and the social determinants of health; evaluation (estimation) of the effects of policies and other factors on health inequalities; promotion of the understanding of the social determinants of health among policymakers, health practitioners, and the public; and a stronger emphasis on the SDH within existing public health research.

These developments demonstrate that, in Europe, health inequalities and the SDH are not subjects for only a small segment of researchers to study. Rather, national governments, the EU, and the WHO have all launched policies to address these issues and numerous individuals involved with public health and other practitioners have started initiatives that span different government departments and professions to solve these problems. This is - at least in part-the result of a growing body of empirical research in social epidemiology. The subtitle of the WHO report on the social determinants of health summarizes it as "The Solid Facts." [9] In addition, a second edition of this report [10] was published in 2003, demonstrating its relevance and the growth in this field.

The purposes of this book include presenting relevant sections of these studies and, following the WHO's third recommendation, to "promote understanding of the social determinants of health among policymakers, health practitioners, and the public."

\section{Interests and Responses to SDH in Japan}

While still more preliminary than the developments in Europe discussed above, Japan is also showing increased interest in the relationship between social inequalities and health, of which the body of research is currently growing $[11,12]$. 
In terms of basic literature that can be read in Japanese, the Tokyo Medical and Dental University's WHO Collaborating Centre for Healthy Cities and Urban Policy Research has published a translation of the WHO report on the social determinants of health [10]. Kenko Kakusa Syakai [Health Gap Society] written by Professor Katsunori Kondo was published in 2005 and Shakai Kakusa to Kenkō [Social Inequalities and Health] was published in 2006 with major contributions from members of the Social Epidemiology Research Group (chaired by Professor Norito Kawakami). In 2007, the Journal of the National Institute of Public Health (known as Hoken Iryō Kagaku in Japanese) published a special feature (vol. 56, no. 2) entitled "Health Inequality and Health Policy: What's Implied?" [13] More translated works available in Japanese include The Health of Nations: Why Inequality is Harmful to Your Health [14], The Status Syndrome: How Social Standing Affects Our Health and Longevity [15], Social Capital and Health [16], and The Impact of Inequality: How to Make Sick Societies Healthier [17]. The authors of the current book have also published a series of articles [18] and books [19-21] concerning societies with health disparities.

Leading figures in social epidemiological research, such as Professors Kawachi (Harvard School of Public Health) and Marmot (University College London), have been invited to academic meetings of the Japanese Society of Public Health. In 2009 , the 68th meeting of the society addressed the issue of social inequality and health via a main symposium, a symposium held in conjunction with the Science Council of Japan, and other venues. Furthermore, in the same year, the society established a working group to address the social determinants of health under its monitoring and reporting committee. Reports on suicide, children, nonregular employment, and the older people were published and the Science Council of Japan submitted their recommendations (see the appendices).

At its workshop for the fiscal year 2007 (held in February 2008), the Japanese Association of Public Health Center Directors chose "Health Disparities and What Is Required of Health Centers" as one of the themes for the workshop, and the Japanese Society of Oral Health chose "Thinking about Health Disparities" as the main theme of its 58th general meeting in October 2009.

Although progress has been slow, developments concerning health disparities have become more widespread in Japan, partly because poverty and social disparities have become highly visible social issues during the 2000s in Japan. In response to health disparity problems, questions are being asked in the National Diet, as well as at the Council for the Reform of Healthcare Services for Older People.

\section{The Importance of the Issue in Public Health}

The effects of SDH and that of health disparities are greater than was generally thought in the past. Research conducted in Japan showed that health disparities can be seen in health-impacting behaviors [22] — notably smoking [23] and exercise $[24,25]$ - as well as in numerous lifestyle diseases, including risk factors for coro- 
nary artery disease [26], stroke [27, 28], high blood pressure [28], and cancer [29]. Health disparities according to social class have also been reported in mental health areas such as depression [20,21,30] and sleep disorders [20], in occupational health areas such as work-related stress [31-34], and in dental health [35]. These areas have all been considered in the Health Japan 21 initiative. These disparities are also major contributing factors in trauma-related deaths [36] and suicides [37], for which the incidence in Japan is higher than most developed countries. SDH are crucial when considering measures to deal with these health issues. As the effects of factors before birth and during early childhood on diseases during adulthood became known, it has become apparent that support for maternal and child health, childrearing support, and the provision of preschool education are also vital. The Japanese Society of Public Health has made proposals [38] that focus on the social determinants of health, including suicide prevention measures and improving measures aimed at the unemployed. Those of lower social classes and who have numerous health problems are particularly unlikely to see doctors [20, 21, 39]. It can be said that this is an important reason why care prevention, preventing functional decline, use of long-term care, and measures to fight metabolic syndrome have not performed as well as was expected [19]. Furthermore, there have been suggestions that the effect of increased co-payments for patient medical fees after reforms to the healthcare system will be to inhibit patients from seeing their doctors [28, 40].

In other words, SDH are closely related to numerous public health, healthcare, and administrative issues, including NCDs and healthy aging, maternal and child health, support for child-rearing, suicide prevention measures, mental health, and reforms of the healthcare system and Health Japan 21. To make these policies, initiatives, and projects more effective, increasing knowledge and understanding of $\mathrm{SDH}$ and formulating policies based on this increased appreciation is crucial.

\section{Summary}

This book discusses various diseases and health problems, focusing on NCDs (see Table 1.2) and healthy aging, and presents the achievements of social epidemiology.

By doing so, the authors of this book clarify and emphasize the importance of health disparities and the SDH in the many public health problems that Japan and other countries are currently facing. The book also addresses both the importance of a life course perspective and the significant relationship between the state of the social environment—including social capital—and health. The authors wish to demonstrate the possibility of measures that may contribute to addressing health issues. This includes health impact assessments, which provide a concrete form to population strategies based on the social realities mentioned above.

The hope of the authors is that those interested in health disparities and SDH will grow in number and that this influence will spill over into other areas and eventually spread across the globe. 
Table 1.2 Topics in this book

\begin{tabular}{l}
\hline Problematic behavior in children \\
\hline Metabolic syndrome \\
\hline Cancer \\
\hline Coronary artery disease \\
\hline Stroke \\
\hline Chronic kidney disease \\
\hline Diabetes \\
\hline Suicide \\
\hline Depression \\
\hline Dementia \\
\hline Falls and broken bones \\
\hline Malnutrition among the elderly \\
\hline Dental problems \\
\hline Life course epidemiology \\
\hline Social capital and health \\
\hline $\begin{array}{l}\text { Access to healthcare and health } \\
\text { disparity }\end{array}$ \\
\hline $\begin{array}{l}\text { Initiatives concerning health } \\
\text { disparity and health impact } \\
\text { assessment }\end{array}$ \\
\hline $\begin{array}{l}\text { What measures can be taken } \\
\text { against health disparity }\end{array}$ \\
\hline Focus on the actions of the WHO \\
\hline
\end{tabular}

\section{References}

1. Jiki Kokumin Kenkōzukuri Undō Puran Sakutei Senmon Iinkai. "Kenkō Nippon 21 (Dai 2-ji) no Suishin ni Kan Suru Sankō Shiryō” Kōsei Kagaku Shingikai Chiiki Hoken Kenkō Zōshin Eiyō Bukai. 2012. http://www.mhlw.go.jp/bunya/kenkou/dl/kenkounippon21_02.pdf.

2. Commission on Social Determinants of Health. Closing the gap in a generation: health equity through action on the social determinants of health. World Health Organisation; 2008.

3. Whitehead M. Diffusion of ideas on social inequalities in health: a European perspective. Milbank Q. 1988;76(3):469-92.

4. Berkman LF, Kawachi I. Social epidemiology. New York: Oxford University Press; 2000.

5. Department of Health. Independent inquiry into inequalities in health: Report (Chairman: Sir Donald Acheson). London: The Stationary Office; 1998.

6. Department of Health. Reducing health inequalities: an action report. London: DoH; 1999.

7. Department of Health. Tackling health inequalities: a programme for action. London: Department of Health; 2003.

8. Hogstedt C, Lundgren B, Moberg H, Pettersson B, Ågren G. Background to the new Swedish public health policy. Scan J Public Health. 2004;32(Supplement 64):6-17.

9. Wilkinson RG, Marmot M, editors. Social determinants of health: the solid facts. Geneva: World Health Organization; 1998.

10. Wilkinson RG, Marmot M, editors. Social determinants of health: the solid facts. 2nd ed. Geneva: World Health Organization; 2003.. http://www.tmd.ac.jp/med/hlth/whocc/pdf/solidfacts2nd.pdf 
11. Fukuda Y, Nakamura K, Takano T. Higher mortality in areas of lower socioeconomic position measured by a single index of deprivation in Japan. Public Health. 2007;121:163-73.

12. Kagamimori S, Gaina A, Nasermoaddeli A. Socioeconomic status and health in the Japanese population. Soc Sci Med. 2009;68(12):2152-60.

13. Kokuritsu Hoken Iryō Kagakuin. Kenkō Kakusa to Hoken Iryō Seisaku. Hoken Iryō Kagaku. 2007; 56(2).

14. Kawachi I, Kennedy B. The health of nations: why inequality is harmful to your health. New York: The New Press; 2002.

15. Marmot M. The status syndrome: how social standing affects our health and longevity. New York: Times Books; 2004.

16. Kawachi I, Subramanian S, Kim D, editors. Social capital and health. New York: Springer Science + Business Media, LLC; 2008.

17. Wilkinson R. The impact of inequality: how to make sick societies healthier. New York: The New Press; 2005.

18. Kondo K. 'Kenkō Kakusa Shakai' e no Shohōsen: Shohō no Tame ni Nani ga Hitsuyō ka. Hokenshi Jānaru. 2006;62(10):854-9.

19. Kondo K. Kenkō Kakusa Shakai: Nani ga Kokoro to Kenkō wo Mushibamu no ka. Tokyo: Igaku Shoin; 2005.

20. Kondo K, editor. Kenshō "Kenkō Kakusa Shakai”: Kaigo Yobō ni Muketa Shakai Ekigakuteki Daikibo Chōsa. Tokyo: Igaku Shoin; 2007.

21. Kondo K. "Kenkō Kakusa Shakai" wo Ikinuku. Tokyo: Asahi Shimbun Shuppan; 2010.

22. Fukuda Y, Nakamura K, Takano T. Accumulation of health risk behaviours is associated with lower socioeconomic status and women's urban residence: a multilevel analysis in Japan. BMC Public Health. 2005;5(1):53.

23. Fukuda Y, Nakamura K, Takano T. Socioeconomic pattern of smoking in Japan: income inequality and gender and age differences. Ann Epidemiol. 2005;15(5):365-72.

24. Takao S, Kawakami N, Ohtsu T. Occupational class and physical activity among Japanese employees. Soc Sci Med. 2003;57(12):2281-9.

25. Kondo K. Karei Suteeji to Undō: Kenkō wo Kettei Suru Yōin: Shakaiteki Yōin to Raifukōsu. Taiiku no Kagaku. 2008;58(12):842-6.

26. Nishi N, Makino K, Fukuda H, Tatara K. Effects of socioeconomic indicators on coronary risk factors, self-rated health and psychologoical well-being among urban Japanese civil servants. Soc Sci Med. 2004;58(6):1159-70.

27. Ichimura H, Hashimoto H, Shimizutani S. Japanese study of aging and retirement: JSTAR first results 2009 report. Tokyo: Research Institute of Economy, Trade and Industry; 2009.

28. Murata C, Yamada T, Chen C-C, Ojima T, Hirai H, Kondo K. Barriers to health care among the elderly in Japan. Int J Environ Res Public Health. 2010;7(4):1330-41.

29. Nishi N, Sugiyama H, Hsu WL, et al. Differences in mortality and incidence for major sites of cancer by education level in a Japanese population. Ann Epidemiol. 2008;18(7):584-91.

30. Murata C, Kondo K, Hirai H, Ichida Y, Ojima T. Association between depression and socioeconomic status among community-dwelling elderly in Japan: the Aichi Gerentological Evaluation Study (AGES). Health Place. 2008;14(3):406-14.

31. Kawakami N, Kobayashi Y, Hashimoto H, editors. Shakai Kakusa to Kenkō Shakai Ekigaku kara no Apurōchi. Tokyo: Tokyo Daigaku Shuppan Kai; 2006.

32. Sekine M, Tatsuse T, Kagamimori S. Nihon, Eikoku, Finrando no Kōmuin ni Okeru Shakaikeizaiteki Jōkyō to Kenkō: Shinrishakaiteki Sutoresu to Kenkō Risuku Kōdō no Yakuwari. Kōsei no Shihyō. 2008;55(11):13-21.

33. Sekine M, Chandola T, Martikainen P, Marmot M, Kagamimori S. Socioeconomic inequalities in physical and mental functioning of British, Finnish, and Japanese civil servants: role of job demand, control, and work hours. Soc Sci Med. 2009;69(10):1417-25.

34. Kawakami N, Haratani T, Kobayashi F, et al. Occupational class and exposure to job stressors among employed men and women in Japan. J Epidemiol. 2004;14(6):204-11. 
35. Aida J, Kondo K. Rensai ‘Kenkō Kakusa Shakai’ e no Shohōsen Bangaihen Shika Shikkan ni Okeru Kenkō Kakusa to Sono Taisaku. Hokenshi Jānaru. 2007;63(11):1038-43.

36. Fujino Y, Tamakoshi A, Iso H, et al. A nationwide cohort study of educational background and major causes of death among the elderly population in Japan. Prev Med. 2005;40(4):444-51.

37. Tanaka T, Kondo K. Jisatsu ni Okeru Shakaikeizai Yōin to Sono Taisaku. Kōshū Eisei. 2010;74(1):78-85.

38. Nihon Kōshū Eisei Gakkai, Kōshū Eisei Monitaringu Repōto Iinkai. Keizai Hendōki no Jisatsu Taisaku no Arikata ni Tsuite. Nihon Kōshū Eisei Zasshi. 2010;57(2):415-8.

39. Hiramatsu M, Kondo K, Hirai H. Kaigo Yobō Shisaku no Taishōsha ga Kenshin wo Jushin Shinai Haikei Yōin: Shakaikeizaiteki Inshi ni Chakumoku Shite. Kōsei no Shihyō. 2009;56(3):1-8.

40. Babazono A, Miyazaki M, Imatoh T, et al. Effects of the increase in co-payments from 20 to 30 percent on the compliance rate of patients with hypertension or diabetes mellitus in the employed health insurance system. Int J Technol Assess Health Care. 2005;21(2):228-33.

Open Access This chapter is licensed under the terms of the Creative Commons AttributionNonCommercial-NoDerivatives 4.0 International License (http://creativecommons.org/licenses/ by-nc-nd/4.0/), which permits any noncommercial use, sharing, distribution and reproduction in any medium or format, as long as you give appropriate credit to the original author(s) and the source, provide a link to the Creative Commons licence and indicate if you modified the licensed material. You do not have permission under this licence to share adapted material derived from this chapter or parts of it.

The images or other third party material in this chapter are included in the chapter's Creative Commons licence, unless indicated otherwise in a credit line to the material. If material is not included in the chapter's Creative Commons licence and your intended use is not permitted by statutory regulation or exceeds the permitted use, you will need to obtain permission directly from the copyright holder. 